\title{
Assessment of Vitamins, Protein Quality and Mineral Bioavailability of Matured Stems of Opuntia dillenii Grown in Nigeria
}

\author{
Amadi, B. A. ${ }^{1}$, Njoku, U. C. ${ }^{1, *}$, Agumuo, E. N. ${ }^{2}$, Amadi, P. U. ${ }^{1}$, Ezendiokwere, O. E. ${ }^{1}$, Nwauche, K. T. ${ }^{1}$ \\ ${ }^{1}$ Department of Biochemistry, Faculty of Science, University of Port Harcourt, Rivers State, Nigeria \\ ${ }^{2}$ Department of Biochemistry, Faculty of Science, Imo State University Owerri, Imo State, Nigeria
}

Copyright $\bigcirc 2017$ by authors, all rights reserved. Authors agree that this article remains permanently open access under the terms of the Creative Commons Attribution License 4.0 International License

\begin{abstract}
The vitamin composition, protein quality and mineral bioavailability of matured stems of Opuntia dillenii were investigated. The sample was analyzed using an automatic amino acid analyzer (JEOL (JLC 500/V) for the assessment of amino acids, and an atomic absorption spectrophotometer for the mineral composition analysis while the vitamin composition was evaluated using spectrophotometric methods. The amino acid composition ranged between $1.31 \mathrm{~g}-20.08 \mathrm{~g} / 100 \mathrm{~g}$. Arginine and leucine had the highest concentration of essential amino acids while glutamate and aspartate were the most abundant non-essential amino acid in the studied plant. The percentage Total essential amino acids (with Histidine), Total non-essential amino acids, Total aromatic amino acids, and Total sulphur amino acids were $41.8 \%, 56.1 \%, 8.1 \%$ and $5.3 \%$ respectively. The results for the protein quality indices: - the predicted protein efficiency ratios (P-PERs I, II, and III) were $2.45,2.59$ and 3.49 respectively. The amino acid scoring pattern showed valine and lysine as the limiting essential amino acids considering the requirements of pre-school children. The vitamin analysis showed that vitamin $B_{12}$ and vitamin $A$ were the most occurring vitamins. The mineral analysis results revealed magnesium, calcium and phosphorus as the most concentrated while the [phytate]/ [calcium] ratio and [phytate]/ [zinc] ratio in the sample were below the critical levels. The study has shown that matured stems of Opuntia dillenii can contribute greatly towards meeting human nutritional requirement and the high vitamin $\mathrm{B}_{12}$ content could be of important value in patients with severe sickle cell disease.
\end{abstract}

Keywords Opuntia dillenii, Amino Acids, Protein Quality, Micronutrients

\section{Introduction}

Opuntia dillenii are part of the Cactaceae family that is extensively distributed in arid and semi-arid regions all over the world [1]. Fresh Cactus pear cladodes are considered as vegetables that originated from tropical America. The fruits and cladodes are generally eaten as a delicacy and they have little shelf life, from 3-4 weeks and are usually sold in the commercial markets in South-Western United States, South Africa, and Northern Mexico [2, 3, 4]. Freshly harvested Cactus pear cladodes regarded as vegetables, present a high water content and minor proportions of dietary fiber, lipids and calcium [5]. They are also rich in antioxidants, such as ascorbic acid, $\beta$-carotene, lutein and xanthophylls $[6,7]$. The plant is known for its medicinal properties that range from auxiliary treatment for obesity, and gastrointestinal or cardiovascular disorders [1], decrease in the levels of cholesterol and serum glucose $[8,9]$. The incidence of drought and minimal rainfall limits the growth of many plant species and under these conditions, prickly pear pads are usually used as food and fodders for human and animal nutrition as a result of its high water use efficiency ratio and low water exigency and also, their ability to thrive under extreme conditions, makes them suitable for extensive cultivation [10]. Protein energy malnutrition and micro nutrient deficiencies remain a huge health burden in developing countries and they are the most notable risk factors globally for illness were a lot of pregnant women and young children are usually affected [11]. Though vitamin D, $\mathrm{C}$, and $\mathrm{B}$ deficiencies have declined considerably in recent decades, deficiencies in iron, iodine and vitamin A remain major public health concerns in developing countries [12, 13]. Accordingly, the availability of plant sources of proteins and micronutrients is crucial as a result of limited and expensive sources of animal proteins and micro nutrients. Currently, concerted efforts are in place towards the development of cheaper sources of proteins from plant origin [14]. Despite that legumes are valuable sources of proteins, their cultivation and production remains inadequate to provide for the nutritional needs of increasing human and animal population [15]. Therefore, the unending quest for 
proteins and micro-nutrients from non-leguminous sources remains a continuous endeavor. Furthermore, the paucity of information as regards to the nutrient composition of Opuntia plants grown in South Eastern Nigeria has also aggravated the investigation of the protein quality and mineral bioavailability of the matured stems of Opuntia dillenii grown in Nigeria.

\section{Materials and Methods}

Sample Collection and Identification

Fresh matured Cactus stems (Opuntia dillenii) were gathered from three farm lands located in Aboh Mbaise Local Government Area of Imo State. The plant was identified and autenticated at the herbarium unit of the Department of Plant Science and Biotechnology, University of Portharcourt Choba.

\section{Sample Preparation}

The stems were thoroughly washed, and the spines were manually removed with clean knives, air dried, and milled into a powder with an electric blender and was stored using air tight sample containers before analysis.

\section{Preparation of Extract}

The powdered sample $(100 \mathrm{~g})$ was introduced into a soxhlet extractor with a reflux condenser attached, and extracted with $500 \mathrm{ml}$ of ethanol for $12 \mathrm{hrs}$. The ethanol solvent was removed by placing the extract on a rotary evaporator, thus concentrating the extract.

\subsection{Amino Acid Determination}

The amino acid analysis was carried out using an automatic amino acid analyzer JEOL (JLC 500/V) according to the methods of [16] with some modifications. The sample was subjected to oxidation in a vacuum under cold condition, which contain 1 gram of the samples in $1 \mathrm{ml}$ of $6 \mathrm{M} \mathrm{HCl}$ in a cyclinder glass tube. Hydrolysis was ensued in a glass tube for 24 hours at $110^{\circ} \mathrm{C}$. Into $5 \mathrm{ml}$ of distilled water the vacuum - dried hydrolysate was added, followed by centrifugation at $3000 \mathrm{rpm}$ for $10 \mathrm{~min}$. with the aid of a pipette the supernatant was collected, filtered using a $0.45-\mu \mathrm{m}$ filter into an Erlenmeyer flask, this was followed by the addition of $5 \mathrm{ml}$ of distilled water. HCL was then removed from the solution using Rotary Vapory Evapometer. Upon drying of the solution sodium acetate buffer was added $(5 \mathrm{ml})$ to dissolve the solution. Using a filter of $0.22-\mu \mathrm{m}$ the solution was filtered. $300 \mu \mathrm{L}$ of the filtrate was used for the analysis. Precisely $50 \mathrm{nmol} / \mathrm{mL}$ was applied on the automatic amino acid analyzer. The tryptophan contents of the alkaline hydrolysates were determined calorimetrically using the methods of Spies and Chambers [18] as modified by Rama Rao et al. [19].

\subsection{Determination of Protein Quality Parameters}

Determination of Protein Quality Parameters The method of Adeyeye [20] was adopted for the determination of TAA (Total Amino Acid), TEAA/TAA (ratio of total essential amino acid to total amino acid), TNEA/TAA (ratio of total non-essential amino acid to total amino acid), TArAA (Total aromatic amino acid), TBAA (Total basic amino acid), TAAA (Total acidic amino acid), and TSAA (Total sulfur-containing amino acid). The regression equation method of Chavan et al. [21] was followed for the determination of the predicted PER (protein efficiency ratio) values of the matured stems of Opuntia dillenii:

$$
\begin{array}{ll}
\text { I. } & \text { PER }=-0.684+0.456(\text { Leu })-0.047(\text { Pro }) \\
\text { II. } & \text { PER }=-0.468+0.454(\text { Leu })-0.105(\text { Tyr }) \\
\text { III. } & \text { PER }=-1.816+0.435(\text { Met })+0.780(\text { Leu })+0.211(\text { His })- \\
& \text { 0.944(Tyr). }
\end{array}
$$

The essential amino acid index (EAAI) was calculated following the method of Steinke et al. [22], as revealed below; $\mathrm{EAAI}=9$

$\mathrm{EAAI}=9 \sqrt{\frac{m g \text { of } \text { Lys } \text { in } 1 \mathrm{~g} \text { of test protein } \times 8 \text { essential amino acids }+ \text { His }}{m g \text { of Lys in } 1 \mathrm{~g} \text { of Reference protein }}}$

The amino acid scores were calculated as follows: Amino acid score $\mathrm{a}=($ amount of amino acid per test protein $(\mathrm{mg} / \mathrm{g}))$ / (amount of amino acid per protein in reference pattern (mg/g)for pre-school child ) FAO/WHO/UNU [23]. Amino acid score $\mathrm{b}=$ ratio of $1 \mathrm{mg}$ of amino acid per $\mathrm{g}$ of test protein to $1 \mathrm{mg}$ of amino acid per $\mathrm{g}$ of standard protein $\times 100$. The reference pattern of essential amino acid requirements ( $\mathrm{g} / 100 \mathrm{~g}$ of protein) as provided by Adeyeye et al. [24] served as the standard.

\subsection{Mineral Content, Mineral Ratio and Phytate Determination}

A mixture of concentrated $\mathrm{HNO} 3$ and $60 \%$ (v/v) $\mathrm{HClO} 4$ was used to digest $(5 \mathrm{ml})$ of the sample using the AOAC [25] method and the digested organic matter in the sample was diluted to a final volume of $25 \mathrm{ml}$ using deionized distilled. The levels of $\mathrm{Na}, \mathrm{K}, \mathrm{Ca}, \mathrm{Fe}, \mathrm{Mg}, \mathrm{p}, \mathrm{Cu}$, and $\mathrm{Zn}$ in the samples were thus evaluated using an atomic absorption spectrophotometer (Buck Scientific model 210 VGP) and flame photometer (Jenway model). The sulphate content of the food sample was determined turbidimetrically according to AOAC [25]. The chloride level was determined titrimetrically using the method of AOAC, [25]. The mineral ratio was determined as described by David [26], while the phytate content was evaluated using the method of Schroeder et al. [27]. The method of Igwe et al [28] was employed for the calculation of $[$ phytate]/[Zn], and [phytate]/ [Ca] as described below;

[phytate] $/[\mathrm{Zn}]=[$ phytate $(\mathrm{mg} / 100 \mathrm{~g}) / 660] /[$ zinc $(\mathrm{mg} / 100 \mathrm{~g})$ / 65.38]

phytate $] /[\mathrm{Ca}]=[$ phytate $(\mathrm{mg} / 100 \mathrm{~g}) / 660] /[$ calcium $(\mathrm{mg} / 100 \mathrm{~g}) / 40.08]$ 


\subsection{Vitamin Content Determination}

Determination of vitamin A was by the method of kirk and sawyer [29]. Determination of Niacin $\left(B_{3}\right)$, vitamin $B_{12}$, vitamin $\mathrm{E}$, vitamin $\mathrm{D}$, and vitamin $\mathrm{K}$ was by spectrophotometric method while pyridoxine (vitamin $\mathrm{B}_{6}$ ) was by titremetry. These methods are as described by AOAC [25]. Ascorbic acid (vitamin C) was determined titremetrically by the method of Barakat et al. [30].

\section{Results and Discussion}

Table 1a. Essential amino acid composition of matured stems of Opuntia dillenii

\begin{tabular}{|c|c|}
\hline Amino acids & Composition $(\mathrm{g} / 100 \mathrm{~g})$ \\
\hline Valine & $1.32 \pm 0.03$ \\
\hline Threonine & $3.54 \pm 0.07$ \\
\hline Isoleucine & $4.42 \pm 0.05$ \\
\hline Leucine & $7.19 \pm 0.05$ \\
\hline Lysine & $4.06 \pm 0.02$ \\
\hline Methionine & $3.22 \pm 0.04$ \\
\hline Phenylalanine & $3.78 \pm 0.10$ \\
\hline Histidine & $2.28 \pm 0.06$ \\
\hline Arginine & $8.62 \pm 0.05$ \\
\hline Tryptophan & $1.31 \pm 0.05$ \\
\hline
\end{tabular}

The values are means of triplicate determinations \pm standard errors of mean (SEM)

Table 1b. Non-essential fatty acid composition of matured stems of Opuntia dillenii

\begin{tabular}{|c|c|}
\hline Amino acids & Composition $(\mathrm{g} / 100 \mathrm{~g})$ \\
\hline Aspartate & $13.33 \pm 0.06$ \\
\hline Proline & $3.53 \pm 0.05$ \\
\hline Glycine & $2.62 \pm 0.09$ \\
\hline Alanine & $5.34 \pm 0.04$ \\
\hline Tyrosine & $2.30 \pm 0.05$ \\
\hline Glutamate & $20.5 \pm 0.01$ \\
\hline Serine & $2.37 \pm 0.06$ \\
\hline Cysteine & $1.63 \pm 0.07$ \\
\hline
\end{tabular}

The values are means of triplicate determinations \pm standard errors of mean (SEM)

The amino acid composition of matured stems of Opuntia dillenii is shown in Table 1a and $1 \mathrm{~b}$. Arginine and leucine exhibited the highest values as regards to the essential amino acid profile of the matured stems of Opuntia dillenii. The high leucine estimate is in agreement with the observations of $[31,32,33]$ in other plants. Leucine enhances the stimulation of protein synthesis in muscles [34] while arginine is an essential amino acid for growth and development of infants. L-arginine as a precursor of nitric oxide plays a key role in nutrient supply, improvements in oxygen circulation and blood flow via the action of nitric oxide on vascular endothelial smooth muscles, and relaxes blood vessels [35]. Lysine, methionine, threonine, isoleucine and phenylalanine estimates were 4.06, 3.22, 3.54, 4.42 and $3.78 \mathrm{~g} / 100 \mathrm{~g}$ respectively. These outlined essential amino acid estimates were similar to the reports of Ogungbenle and
Otemuyiwa [36] for Celosia spicata leaves and Akubugwo et al. [33] for Amaranthus hybridus leaves. Dietary sources of lysine are crucial in abnormal conditions of the immune system arising from lysine deficiency [37], methonine plays a key role in choline synthesis while lameness and neurologic dysfunction are consequences of threonine deficiency [38], Phenylalanine is the precursor of some hormones and the pigment melanin in hair, eyes and tanned skin [24] while isoleucine may reduce fat deposition and weight gain [39]. Valine and tryptophan were the least occuring essential amino acid in the studied plant. Glutamate and aspartate were the highest occurring non-essential amino acid present in the sample and similar observations have been reported by $[33,36,40]$. Most of the essential amino acids estimates present in the sample are in line with the amino acid reference values recommended for pre-school children, children already in school and adults, FAO/WHU/UNU [23].

Table 2. Total amino acids, amino acid groups and Protein Quality of matured stems of Opuntia dillenii

\begin{tabular}{|c|c|}
\hline Parameters & Value $(g / 100 g)$ \\
\hline \multicolumn{2}{|l|}{ \% Amino acid contents } \\
\hline \%TNEAA & 56.19 \\
\hline \%TEAA(with His) & 41.83 \\
\hline \%TEAA(without His) & 41.19 \\
\hline \%TArAA & 8.12 \\
\hline$\%$ TBAA & 16.45 \\
\hline$\%$ TAAA & 37.20 \\
\hline$\%$ TSAA & 5.33 \\
\hline$\%$ TBCAA & 14.21 \\
\hline \multicolumn{2}{|l|}{ Amino acid groups } \\
\hline Total amino acid (TAA) & 90.94 \\
\hline Total non-essential amino acid (TNEAA) & 51.10 \\
\hline Total essential amino acid (TEAA) with His & 39.74 \\
\hline Total essential amino acid (TEAA) without His & 37.46 \\
\hline Total aromatic amino acid (TArAA) & 7.39 \\
\hline Total basic amino acid (TBAA) & 14.96 \\
\hline Total acidic amino acid (TAAA) & 33.83 \\
\hline Total sulphur amino acid (TSAA) & 4.83 \\
\hline Total branched chain amino acid (TBCAA) & 12.93 \\
\hline \multicolumn{2}{|l|}{ Protein Quality Indices } \\
\hline Predicted protein efficiency ratios (P-PERs) I & 2.45 \\
\hline II & 2.59 \\
\hline III & 3.49 \\
\hline Essential amino acid index (EAAI) & 1.40 \\
\hline Leu/Ile & 1.62 \\
\hline TEAA (+His) /TAA & 0.43 \\
\hline TEAA (-His) /TAA & 0.41 \\
\hline TBAA/TAAA & 0.34 \\
\hline Cys in TSAA & 1.61 \\
\hline$\%$ Cys in TSAA & 33.33 \\
\hline
\end{tabular}

The total amino acid, amino acid groups, percentage constituents and protein quality indices of matured stems of Opuntia dillenii are shown in Table 2. The sample exhibited a total amino acid content of $90.94 \mathrm{~g} / 100 \mathrm{~g}$ comprising of $51.10 \mathrm{~g} / 100 \mathrm{~g}(56.19 \%)$ total non-essential amino acids, 
$39.74 \mathrm{~g} / 100 \mathrm{~g}(43.69 \%)$ total essential amino acid with histidine and $37.46 \mathrm{~g} / 100 \mathrm{~g}(41.19 \%)$ total essential amino without histidine. The $90.94 \mathrm{~g} / 100 \mathrm{~g}$ total amino acid content of the sample was comparably higher than the values reported for Crassocephalum crepidioides and Senecio biafrae green leafy vegetables [41] and $53.91 \mathrm{~g} / 100 \mathrm{~g}$ for Terminalia littoralis [42] but comparable to the $88.41 \mathrm{~g} / 100 \mathrm{~g}$ for D. edulis seed and seed coat mixture [40] and within the range (70.3-91.8g/100g) reported by Adeyeye [43] for dehulled African yam bean. The total branched chain amino acids (TBCAA) $12.93 \mathrm{~g} / 100 \mathrm{~g}$ observed in the current sample was comparable to the $13.39 \mathrm{~g} / 100 \mathrm{~g}$ value reported for Terminalia Iittoralis [42]. Leucine, isoleucine and valine are branched chain amino that are attributed as quality sources of energy. Consequently, The TBCAA contents suggest that more than $20 \%$ of its TAA may supply energy to the body [42]. The FAO requirement [23] for essential amino acids without Histidine $(35.0 \mathrm{~g} / 100 \mathrm{~g})$ was comparable to the $(37.46 \mathrm{~g} / 100 \mathrm{~g})$ value for essential amino acids without Histidine present in the studied sample. The total TAAA content in the sample clearly indicates that the protein species may be acidic in comparison to the TBAA value while the total TNEAA value of $(51.10 \mathrm{~g} / 100 \mathrm{~g})$ in comparison to the TEAA with His $(39.74 \mathrm{~g} / 100 \mathrm{~g})$ implies that the sample contains lower essential amino acids than the non-essential amino acids and therefore, should be supplemented with other rich sources of essential amino acids for proper nutritional benefits. The TEAA content $(39.74 \mathrm{~g} / 100 \mathrm{~g})$ was lower than the value for egg reference protein $(56.6 \mathrm{~g} / 100 \mathrm{~g})$ reported by Paul et al. [44] but comparably close to the values $(44.4 \mathrm{~g} / 100 \mathrm{~g})$ for soya bean [45], 43.1g/100g for Bridelia ferruginea stem bark [46] and $41.83 \mathrm{~g} / 100 \mathrm{~g}$ for $D$. edulis seed and seed coat mixture [40]. The percentage essential amino acid content with histidine $(41.8 \%)$ and without histidine $(41.1 \%)$ were above the values recommended for infants $(39 \%)$, children (26\%) and adults (11\%) [23] and comparably close to the values for egg [47].The TArAA value of the studied sample fell within the accepted protein range $(6.8-11.8 \mathrm{~g} / 100 \mathrm{~g})$ for infants as recommended by $\mathrm{FAO} / \mathrm{WHO} / \mathrm{UNU}$ [23]. The TSAA composition was favorably comparable to the $5.8 \mathrm{~g} / 100 \mathrm{~g}$ of crude protein for infants [23]. The TSAA composition implies that the sample contained more methionine than cysteine and many vegetables contain more amounts of cysteine than methionine [46], cysteine has been attributed to exert immense benefits in the absorption of zinc [48]. The P-PERs values were higher than the values (1.21) for cowpea [49], millet and ogi (1.62 and 0.27) [50]. Predicted protein efficiency ratios are useful quality parameters in protein evaluation [51] and EAAI is useful as well during protein quality evaluation in food formulations. The EAAI of the present study 1.40 was higher than the values for soy flour [52], raw and cooked groundnut seeds [20]. Some studies have demonstrated the importance of leucine/isoleucine balance in the regulation of tryptophan and niacin metabolism as a result of the impairment of tryptophan metabolism and niacin deficiency caused by excessive amounts of leucine [53]. The present Leu/ileu ratios were low in value (1.62) and lower than 1.89 recorded for D.eludis seed and seed coat mixture [40], 1.60 and 1.50 respectively for the yolk and albumin of guinea fowl [54].

Table 3. Amino Acids Scores (g/100g protein) of the matured stems of Opuntia dillenii

\begin{tabular}{|c|c|c|}
\hline Amino acid & Score $^{\text {a }}$ & Score $^{\text {b }}$ \\
\hline Leucine & 1.09 & 1.02 \\
\hline Threonine & 1.04 & 0.88 \\
\hline Tryptophan & 1.19 & 1.31 \\
\hline Lysine & 0.70 & 0.73 \\
\hline Phenylalanine + Tyrosine & 0.96 & 1.01 \\
\hline Isoleucine & 1.57 & 1.10 \\
\hline Valine & 0.37 & 0.27 \\
\hline Methionine + Cysteine & 1.93 & 1.38 \\
\hline
\end{tabular}

Score $\mathbf{a}=$ Essential amino acid scores based on requirements of pre-school child FAO/WHO/UNU [23]. Score b = Essential amino acid scores based on the provisional amino acid scoring pattern $(\mathrm{g} / 100 \mathrm{~g}$ of crude protein) [24]

The essential amino acid scores of matured stems of Opuntia dillenii are presented in Table 3. The essential amino acids with the highest scores greater than 1.0 in both scoring patterns include methionine + cysteine $(1.93$ and 1.38), isoleucine (1.57 and 1.10), Tryptophan (1.19 and 1.31) and leucine (1.09 and 1.02) while the essential amino acids that were less than 1.0 in both scoring patterns are valine (0.37 and 0.27$)$ and lysine (0.70 and 0.73$)$. This outcome shows that valine and lysine are the limiting essential amino acids in the studied sample.

Table 4. Phytate and Mineral Composition (mg/100g) of matured stems of Opuntia dilleni

\begin{tabular}{|c|c|}
\hline Parameters & Value $(\mathrm{mg} / \mathrm{kg})$ \\
\hline Phytate & $4.60 \pm 0.64$ \\
\hline Micro minerals & \\
\hline Zinc & $9.46 \pm 0.03$ \\
\hline Copper & $0.17 \pm 0.04$ \\
\hline Selenium & $1.01 \pm 0.04$ \\
\hline Lead & $0.68 \pm 0.00$ \\
\hline Cadmium & $0.47 \pm 0.06$ \\
\hline Iron & $9.48 \pm 0.05$ \\
\hline Macro minerals & $60.65 \pm 0.05$ \\
\hline Magnesium & $31.68 \pm 0.06$ \\
\hline Calcium & $16.62 \pm 0.03$ \\
\hline Sodium & $9.96 \pm 0.12$ \\
\hline Potassium & $19.11 \pm 0.70$ \\
\hline Phosphorus & \\
\hline
\end{tabular}

Values are means of three determinations \pm standard errors of mean (SEM)

The micro and macro minerals composition of the matured stems of Opuntia dillenii are shown in Table 4. The results indicate that the ashes of the studied sample are rich in macro-minerals such as magnesium $(60 \mathrm{mg} / 100 \mathrm{~g})$ and calcium $(31.68 \mathrm{mg} / 100 \mathrm{~g})$. Minerals are vital in human nutrition and also necessary for proper health. Enzymatic 
activities, electrolytic balance of the blood fluid and metal deficiency syndromes such as bone calcification and rickets are associated with the sufficiency of $\mathrm{Na}, \mathrm{K}, \mathrm{Mg}, \mathrm{Ca}$ and $\mathrm{Zn}$. Tegene et al. [55] reported calcium, magnesium and potassium as the major mineral constituents in Opuntia ficus indica stems and also, Rodriguez-Garcia et al., [56] posited that stem flours of Opuntia ficus indica are important foods for humans as a result of their composition of essential vitamins and minerals such as potassium and calcium among other elements. The substantial amounts of these macro-minerals present in the studied sample suggest that the matured stems could be of great value in cases of nutritional deficiencies particularly when it is used in diet supplementation. The highest occurring micro minerals in the sample were zinc and iron while lead and cadmium exhibited low concentrations. Zinc acts as a co-factor in numerous enzymatic reactions involving dehydrogenases and polymerases in addition to its effectiveness in cell replication and micro nutrient metabolism [57] while iron deficiency leads to anaemic conditions [58]. Furthermore, the lead and cadmium levels in the sample were low. In animal diets, the maximum concentration of cadmium tolerated is $0.5 \mathrm{mg} / \mathrm{kg}$ [59] while the maximum acceptable limit for lead in fruits and drinks is $0.08 \mathrm{mg} / \mathrm{kg}$ [60]. In mineral mixture, the maximum acceptable concentration of lead is $10 \mathrm{mg} / \mathrm{kg}$ [61]. It is necessary that they exhibit very low levels in food materials as a consequence of the deleterious effect they confer such as inhibition of some anti-oxidants enzymes and reproductive toxicities [62].

Table 5. Calculated Mineral ratios and Phytate-Mineral Ratios of matured stems of Opuntia dillenii

\begin{tabular}{|c|c|}
\hline Parameters & Ratio \\
\hline $\mathrm{Na} / \mathrm{K}$ & 1.66 \\
\hline $\mathrm{Ca} / \mathrm{K}$ & 3.18 \\
\hline $\mathrm{Ca} / \mathrm{Mg}$ & 0.52 \\
\hline $\mathrm{Ca} / \mathrm{P}$ & 1.65 \\
\hline $\mathrm{Zn} / \mathrm{Cu}$ & 55.64 \\
\hline $\mathrm{Fe} / \mathrm{Cu}$ & 55.76 \\
\hline$[\mathrm{Phy}] /[\mathrm{Zn}]$ & 0.04 \\
\hline$[\mathrm{Phy}] /[\mathrm{Ca}]$ & 0.07 \\
\hline
\end{tabular}

The calculated mineral ratios and phytate-mineral ratios are shown in Table 5 . The $\mathrm{Ca} / \mathrm{K}, \mathrm{Ca} / \mathrm{P}$ ratios in the studied sample were more than the minimum ratio needed for sufficient intestinal absorption of calcium [40]. Consequently, the consumption of these matured stems may support the formation of strong bones and teeth. The $\mathrm{Na} / \mathrm{K}$ ratio is crucial in the prevention of cardiovascular diseases and high blood pressure. The $\mathrm{Na} / \mathrm{K}$ ratio in this study was 1.64 and the recorded value exceeds the $<1$ value recommended in food substances [40]. This outcome suggests that the matured stems of Opuntia dillenii may not be ideal for high blood pressure patients. The $\mathrm{Zn} / \mathrm{Cu}$ ratio is vital in the maintenance of the oxidant/antioxidant balance and values $>16$ may lead to changes in the oxidant/antioxidant balance [63]. The $\mathrm{Zn} / \mathrm{Cu}$ ratio recorded in the study exceeded the acceptable range. The phytate content $(4.60 \mathrm{mg} / 100 \mathrm{~g})$ of the studied plant was slightly higher than the range $(2.64-3.90)$ reported for varieties of Abelmoschus esculentus [64]. However, the phytate composition of these matured stems was in the same range of phytic acid reported for Nigerian vegetables [64]. Phytic acid influences the bioavailability of some essential mineral nutrients in the digestive tract through the formation of insoluble mineral chelate at physiological $\mathrm{pH}$ which leads to mineral deficiencies [65]. The [phytate]/ [calcium] ratio in the studied plant was below the critical level of 0.2 [66] and also, the [phytate]/ [zinc] ratio in the sample was below the critical level of 10 [66]. This implies that the phytate content of the matured stems of Opuntia dillenii may not impair the bioavailability of calcium and zinc.

Table 6. Vitamin composition of the matured stems of Opuntia dillenii

\begin{tabular}{|c|c|}
\hline Vitamins & Value $(\mathrm{mg} / \mathrm{kg})$ \\
\hline Vitamin E & $2.44 \pm 0.03$ \\
\hline${\text { Vitamin } \mathrm{B}_{6}}$ & $0.24 \pm 0.01$ \\
\hline${\text { Vitamin } \mathrm{B}_{3}}$ & $1.76 \pm 0.06$ \\
\hline Vitamin A & $35.84 \pm 0.35$ \\
\hline Vitamin C & $8.35 \pm 0.08$ \\
\hline Vitamin D & $12.66 \pm 0.06$ \\
\hline Vitamin $\mathrm{K}$ & $3.05 \pm 0.01$ \\
\hline Vitamin $\mathrm{B}_{12}$ & $140.27 \pm 0.49$ \\
\hline
\end{tabular}

Values are means of three determinations \pm standard errors of mean (SEM)

The vitamin compositions of the matured stems of Opuntia dillenii are presented in Table 6. The results show that the matured stems of the sample are rich in vitamins and the presence of these vitamins in substantial amount in the plant elucidates the significance of vitamin quantification which includes growth and proper immune function, normal vision, cell development, gene expression and maintenance of epithelial cell functions [67]. Studies have demonstrated the benefits of vitamin $B_{12}$, and a reduction in vitamin $B_{12}$ levels was observed in patients with severe sickle cell disease. There was significant symptomatic improvement as a result of treatment with vitamin $B_{12}, 1 \mathrm{mg}$ intramuscularly weekly for twelve weeks in patients with low vitamin $B_{12}$ levels [68]. Natural ascorbic acid is important for proper body function and the deficiency of ascorbic acid interferes with the normal formation of intracellular substances which could lead to impaired growth and development in the body, it is also crucial in the maintenance and repair of tissues such as bones, skin and teeth. Vitamin A, abundant in carrots and sweet potatoes was found in substantial amount $(35 \mathrm{mg} / 100 \mathrm{~g})$ in the matured stems of Opuntia dillenii. Vitamin A is vital for proper vision and regular cell growth and also in the production of white blood cells for proper immune function. The antioxidant vitamins (A, C and E) were present in these matured stems and they neutralize free radicals that can 
accumulate in the body which in turn, leads to aging and some diseases [69]. These observations are similar to the reports of Shade et al [70] who posited that vegetables are important sources of protective foods that are highly valuable in the maintenance of good health and prevention of diseases and thus the matured stems of Opuntia dillenii could have ameliorative effects if supplemented with other anti-oxidant rich plants on diseases associated with oxidative stress.

\section{Conclusions}

The present study has shown that matured stems of Opuntia dillenii posses good potentials in terms of food value as a result of the appreciable level of nutrients which are readily available and can contribute greatly towards disease prevention if consumed in sufficient amount. However, the studied plant contained higher proportion of non essential amino acids to essential amino acids and this implies that they must be supplemented with good sources of animal or plant proteins such as soya bean and cereal to enhance the protein and energy content for growth and adequate protection against diseases associated with malnutrition.

\section{Conflict of Interest}

The authors declare no conflict of information regarding this manuscript.

\section{REFERENCES}

[1] D. Butera, L. Tesoriere, F. Di Gaudio, Antioxidant activities of Sicilian Prickly pear (Opuntia ficus- indica) fruit extract and reducing properties of its Betalains; Betanin and Indicaxanthin. J.Agric and Food Chem; 50 (2002) 6895-6901.

[2] C.H. Russel, P. Felker, The prickly pears (Opuntia Spp. Cactaceae) a source of human and animal food in semi-arid regions. Soci. Eco. Botany, 41(1987) 433-445.

[3] A. Pigga, A. Del Caro, M. Agabbio, Changes in ascorbic acid, polyphenol content and antioxidant activity in minimally processed Cactus pear fruit. LWT- Food Sci. and Tech, 36 (2003) 257-262.

[4] S.H. Guzman-Maldonado, G. Herrera-Hernandez, D. Hernandez-Lopez, Physiochemical, nutritional and functional characteristics of two underutilized fruits Cactus Species (Myrtillo cactus) produced in Central Mexico. Food Chem, 121 (2010) 381-386.

[5] J. Lopez-Cervantes, D.I. Sanchez-Machado, O.N. Campas-Baypoli, C. Beuno-Solano, Functional properties and proximate composition of Cactus pear cladodes flours. Food Sci. Tech 31(2011) 654-659.
[6] A. Rodriguez-Felix, M. A. Villegas-Ochoa, Quality of cactus stems (Opuntia ficus-indica) during low temperature storage. J. Pro. Associ. Cactus Dev, 2(1997) 142-152.

[7] M.A. Bentacourt-Dominguez, T. Hernandez-Perez, P. Garcia-Saucedo, (2006) Physiochemical changes in cladodes (Nopalitos) from cultivated and wild Cacti (Opuntia spp.) Plant Foods for Human Nutri. 61(2006) 115-119.

[8] S. OU, et al. In vitro study of possible role of dietary fiber in lowering postprandial serum glucose. J. Agric. and Food Chem, 49(2001) 1026-1029.

[9] C.J. O'CONNOR, et al. Effect of soluble dietary fibers on lipase-catalyzed hydrolysis of tributyrin. J. Food Sci. 68(2003) 1093-1099.

[10] A. Dominguez-Lopez, Use of Opuntia fruits and stems of the Prickly pear cactus (Opuntia Spp) into Human food. Food Sci. Tech. 1(1995) 65-69.

[11] O. Muller, M. Krawnkel, Malnutrition and health in developing countries. CMAJ 173(2005) 279-286.

[12] H.M. Levin, E. Pollitt, R. Galloway, J. McGuire, Micronutrient deficiency disorders. In: Jamison DT, Mosley WH, Measham AR, Bobadilla JL, editors. Disease control priorities in developing countries. 2nd ed., Oxford (UK): Oxford University Press 1993, pp. 421-451.

[13] J.R. Diaz, A. de las Cagigas, R. Rodriguez, Micronutrient deficiencies in developing and affluent countries [review]. Eur J Clin Nutr, 57(2003) S70-2.

[14] T. Fatoumata, A. Tidjani, L. Camel, L. Guo-Wei, S.Yong-Hui, Extraction, characterization, nutritional and functional properties of Roselle (Hibiscus sabdariffa) seed proteins. Songklanakarin J. Sci. Technol. 35(2013) 159-166.

[15] P. Siddhuraju, K. Becker, Antioxidant properties of various solvent extracts of total phenolic constituents from three different agro-climatic origins of drumstick tree (Moringa oleifera Lam.). J. Agri. and Food Chem. 51(2003) 2144-2155.

[16] R. Adini, S. Yoshida, R. Ohsawa, Variation in Protein Content and Amino Acids in the Leaves of Grain, Vegetable and Weedy Types of Amaranths. Agronomy 2013, 3, 391-403

[17] S. Moore, W.H. Stein, Chromatographic amino acids determination by the use of automatic recording equipment. Methods Enzymol 6(1963) 819-831.

[18] J.R. Spies, D.C. Chamber, Chemical determination of tryptophan in proteins. Anal. Chem. 21(1994) 1249-1266.

[19] M.V.Rama Rao, M.R. Tara, C.K. Krishnan, (1974). Colourimetric estimation of tryptophan content of pulses. J. Food Sci. Tech. (Mysore), 11(1974) 13-216.

[20] E.I. Adeyeye, Effect of cooking and roasting on the amino acid composition of raw groundnut (Arachis hypogaea) seeds. Acta Sci. Pol. Technol. Aliment. 9 (2) (2010) 201-216.

[21] U.D. Chavan, D.B. Mckenzie, F. Shahidi, Functional properties of protein isolates from beach pea (Lathyrus maritius L.). Food Chem. 74, (2001)177-187.

[22] F.H. Steinke, E.E. Prescher, D.T. Hopkins, Nutritional evaluation (PER) of isolated soybean protein and combinations of food proteins. J. Food Sci. 45(1980) 323-327. 
[23] FAO/WHO/UNU, Energy and Protein requirements. Technical report series, Geneva, (1985) 275, pp.204

[24] E.I. Adeyeye, O.T. Orisakeye, M.A. Oyarekua, "Composition, mineral safety index, calcium, zinc and phytate interrelationships in four fast-foods consumed in Nigeria" Bull. Chem. Soc. Ethiop., 26(1) (2012) 43-54.

[25] AOAC, Official Methods of Analysis $15^{\text {th }} \mathrm{ed}$, Association of Official Analytical Chemists, Washington, DC, USA, (1990) PP: 200-210.

[26] L.W. David "HTMA Mineral Ratios, a Brief Discussion of their Clinical Importance". Trace Elements Newsletter.(2010) $21: 1$

[27] W.A. Schroeder, L.M. Kay, R.S. Mills, Anal. Chem., (1990) Pp 22, 760

[28] C.U. Igwe, C.O Ibegbulem, L.A. Nwaogu, C.O. Ujowundu, G.N. Okwu, Calcium, Zinc and Phytate Interrelationships in Four Lesser-Known African Seeds Processed into Food Condiments. J. Adv.Chem 4(2013) 288-292.

[29] R.S. Kirk, R. Sawyer, (1991). Pearson food composition and analysis $9^{\text {th }}$ ed. Addison Wesley Longman Ltd, England (1991) pp 188-189.

[30] M.Z. Barakat, S.K. Shehab, N. Darwish, E.I. Zahermy, Determination of ascorbic acid from plants. Anal. Biochem. 53(1973) 225-245.

[31] O. Olaofe, E.T. Akintayo, Prediction of isoelectric points of legume and oilseed proteins from their amino acid compounds. J. Techno-Sci. 4 (2000) 49-53.

[32] E. Adeyeye, The chemical composition of liquid and solid endosperm of ripe coconut. Orient. J. Chem. 20(2004) $471-478$

[33] I.E. Akubugwo, N.A. Obasi, G.C. Chinyere, A.E. Ugbogu, Nutritional and chemical value of Amaranthus hybridus $L$. leaves from Afikpo, Nigeria. Afri. J. Bio, 6 (2007) 2833-2839.

[34] M.R. Etzel, "Manufacture and use of dairy protein fractions". $J$. Nutr. 134 (2004): 996S-1002S.

[35] L.J. Ignarro, Nitric oxide: a unique endogenous signaling molecule in vascular biology. Bioscience reports, 19(1999) 51-71.

[36] H.N. Ogungbenle, F.F. Otemuyiwa, Food properties and amino acid composition of Celosia spicata Leaves. Adv.Anal. Chem. 5(2015) 1-7

[37] C. Chen, J.E. Sander, N.M. Dale, "The effect of dietary lysine deficiency on the immune response to Newcastle disease vaccination in chickens". Avian Dis. 47 (2003): 1346-51

[38] C.A. Titchenal, Q.R. Rogers, R.J. Indrieri, J.G. Morris, Threonine imbalance, deficiency and neurologic dysfunction in the kitten. J Nutr. 110(1980) 2444-59.

[39] J. Nishimura, T. Masaki, M. Arakawa, M. Seike, H. Yoshimatsu, (2010) "Isoleucine prevents the accumulation of tissue triglycerides and upregulates the expression of PPAR $\gamma$ and uncoupling protein in diet-induced obese mice," J. Nutri. 140(2010) 496-500.

[40] C.U. Ogunka-Nnoka, P.U. Amadi, P.C. Ogbonna, P.O. Ogbegbor, Assessment of the protein quality and mineral bioavailability of Dacryodes edulis seed and seed coat mixture, J.Sci. Res \& Rep, 14(2017) 1-11

[41] F.A. Dairo, I.G. Adanlawo, Nutritional quality of Crassocephalum crepidioides and Senecio biafrae. Pakis. J. Nutr. 6 (2007): 35-39.

[42] C.O. Ibegbulem, Nutritional effects of drinking Terminalia littoralis Seem. Decoction, Int. J.Biochem. Rev. 2(2012) 126-136.

[43] E. I. Adeyeye, (1997) Amino acid composition of six varieties of dehulled African yam bean (Sphenostylis stenocarpa) flour, Int. J. Food Sci. Nutr. 48(1997) 345-351

[44] A.D. Paul, A.T. Southgate, J. Russel, First supplement to McCance and Widdowson's. The composition of foods. HMSO, London (1976)

[45] A.M. Altschul, Processed plant protein foodstuff. Academic press, New York (1958).

[46] A.A. Jonathan, A.S. Funmilola, (2014) Nutritional and anti-nutritional composition of Bridelia ferruginea Benth (Euphorbiaceae) stem bark. Int. J. Sci. Res Kno. 2 (2014) 92-104.

[47] FAO/WHO, Protein quality evaluation Report of Joint FAO/WHO Expert Consultation. FAO Food and Nutrition Paper 51. FAO Rome (1990).

[48] C. Mendoza, Effect of genetically modified low phytic acid plants on mineral absorption. Int. J. Food Sci. and Nutr. 37(2002) 759-767.

[49] D.K. Salunkhe, S.S. Kadam, Handbook of world food legumes, nutritional chemistry, processing technology and utilisation. Boca Raton, CRC Press Florida (1989).

[50] M.A. Oyarekua, A.F. Eleyinmi, Comparative evaluation of the nutritional quality of corn, sorghum and millet ogi prepared by modified traditional technique. Food Agric. Environ. 2 (2004) 94-99.

[51] FAO/WHO, Protein quality evaluation. Report of Joint FAO/WHO Expert Consultation. FAO Food and Nutrition Paper 51. FAO Rome (1991).

[52] S.S. Nielson, Introduction to the Chemical Analysis of Foods, CBS Publishers and Distributors, New Delhi (2002).

[53] S. Ghafoorunissa, B.S. Narasinga Rao, Effect of leucine on enzymes of the tryptophanniacin metabolic pathway in rat liver and kidney. Biochem. J. 134(1973)425-430.

[54] E.I. Adeyeye, Evaluation of the amino acid profile of the yolk and albumen of guinea fowl (Numida meleagris) egg. Applied Biol, 47(2012) 8799-8803.

[55] F. Tegegne, Nutritional value of Opuntia ficus-indica as a ruminant feed in Ethiopia. FAO Plant Production and Protection Papers, (2001) 91-100.

[56] M.E. Rodriguez-Garcia, C. De-Lira, M.A. Hernandez-Becerra, A.J. Cornejo-Villegas, T. Palacios-Fonesca, R. Rojas-Molina, L.C. Regnoso, T.A. Zepeda, Physiochemical characterization of nopal pads (Opuntia ficus indica) and dry vacuum nopal powders as a function of the maturation. Plant Foods Human Nutrition, 62(2007) 107-112.

[57] O.G. Arinola, Essential trace elements and metal binding 
proteins in Nigerian consumers of alcoholic beverages. Pak. $J$. Nut. 7(2008) 763-765.

[58] A. McDonald, R.A. Edwards, F.D. Greenhulgh, C.A. Morgan, Animal Nutriton.Prentices Hall, London (1995) Pp101-122.

[59] National Research Council (NRC). Minerals In: National Research Council, editors. Nutrient requirement of dairy cattle. Washington: National Academy Press; 2001.p. 54-74

[60] L.S. Reis, P.E. Pardo, A.S. Camargos, E. Oba, Mineral element and heavy metal poisoning in animals. Journal of Medicine and Medical Sciences 1:560-579 2010

[61] W.S. Marcal, L. Gaste, E.B. Veras, A.M. Moreno, Levels of lead in mineral salt commercial mixtures for beef cattle. J. vet. Sci. 4:235-238 2005

[62] J.P. Bonde, M. Joffe, P. Apostoli, A. Dale, P. Kiss, M. Spano, Sperm count and chromatin structure in men exposed to inorganic lead: lowest adverse effect levels. Occup. Environ. Med. 59(2002): 234-242.

[63] H. Zorica, C. Aida, K. Aldina, S. Mirzeta, Zinc/Copper Ratio in the Medicinal Plants 17th International Research/Expert Conference "Trends in the Development of Machinery and Associated Technology" TMT, Istanbul, Turkey (2013).

[64] F.O. Adetuyi, A.U. Osagie, A.T. Adekunle, (2011) Nutrient, anti-nutrient, mineral and bioavailability of okra Abelmoschus esculentus (L) Moench. Am. J. Food Nut., 1:49-54.

[65] E.O. Udosen, U.M. Ukpanah, The toxicants and phosphorus content of some Nigerian vegetables. Pl. Foods H. Nutr. (Formerly Qualitas Plantarum), 44(1993), 285-289.

[66] L.G. Hassan, K.J. Umar, S.M. Dangoggo, A.S. Maigandi, Anti-nutrient composition and bioavailability prediction as exemplified by calcium, iron and zinc in Melocia corchorifolia leaves, Pak J. of Nut. 10 (2011): 23-28

[67] C.E. Achikanu, P.E. Eze-Steven, C.M. Ude, O.C. Ugwuokolie, Determination of the vitamin and mineral composition of common leafy vegetables in south eastern Nigeria. Int.J.Curr Micro. App Sci. 2(2013): 347-353.

[68] N.A. Imaga, Phytomedicines and Nutraceuticals: Alternative therapeutics for Sickle cell anemia. Sci. W. J. Article ID 269659, (2013)12 Pages.

[69] M.A. Wyatt, J.O. Waits, N. Hongu, (2014) Vitamin C and the common cold. https://extention.arizona.edu/sites/extension.arizona.edu/files/ pubs/az1618.pdf (accessed 14.04.17)

[70] A.D. Shade, S. Ashley, E. Kent, J. Jones, E. Ryan, D. Newton, M. Katherine, Inter annual dynamics and phenology of bacterial communities in Eutrophic Lake. Oceanograp, 52(2004) 487-494. 